\title{
Pemanfaatan Kotoran Kuda Sebagai Bahan Dasar Pembuatan Pupuk di Desa Binoh Burneh
}

\author{
Achmad Fachruddin Syah \\ Program Studi Ilmu Kelautan Fakultas Pertanian \\ Universitas Trunojoyo Madura \\ E-mail : fachrudinsyah@gmail.com \\ DOI: http://dx.doi.org/10.21107/pgd.v5i1.5164
}

\begin{abstract}
Artikel Diterima : 21 Januari 2019/ Revisi : 3 Maret 2019/Terbit : 15 April 2019
Abstrak

Salah satu faktor penting dalam menunjang keberhasilan budidaya tanaman adalah ketersediaan unsur hara. Upaya yang bisa dilakukan dalam penyediaan unsur hara adalah dengan menambahkan pupuk organik. Kotoran kuda merupakan salah satu bahan yang dapat dijadikan sebagai bahan dasar dalam pembuatan pupuk organik. Tujuan kegiatan ini adalah untuk memanfatkan kotoran kuda sebagai salah satu bahan dasar pembuatan pupuk organik dan memanfaatkan hasilnya untuk vertikultur. Kegiatan in $\mathrm{i}$ dilakukan di Desa Binoh, Kecamatan Burneh, pada tanggal 11 Januari 2019. Secara umum, kegiatan yang melibatkan kelompok tani dan ibu-ibu rumah tangga, ini berjalan dengan lancar dan sukses. Hal ini terlihat dari semangat dan antusiasme para peserta dalam mengikuti kegiatan ini. Berdasarkan vertikultur yang sudah dibuat dengan campuran pupuk dari kotoran kuda tersebut hasilnya dapat dikatakan berhasil karena tanaman yang berupa sayuran yang ditanam dapat tumbuh dengan baik.
\end{abstract}

Kata Kunci : pupuk organik, kotoran kuda, kecamatan Burneh

\section{PENDAHULUAN}

Penggunaan pupuk mempunyai peranan yang sangat penting untuk menambah kebutuhan unsur hara tanaman. Pemberian pupuk yang tepat dan unsur hara yang seimbang dilakukan untuk mendapatkan pertumbuhan dan hasil tanaman yang diharapkan. Salah satu upaya untuk memperoleh produksi yang baik dan berkualitas yang tinggi adalah pemberian hara yang optimum terutama N dan K (Kofranek, 1980).

Secara umum ada 2 jenis pupuk yaitu pupuk organik dan pupuk anorganik. Pupuk anorganik memegang peranan penting untuk menambah kebutuhan unsur hara tanaman. Keunggulan sifat dari pupuk ini adalah memiliki unsur hara dalam bentuk tersedia sehingga dapat langsung dimanfaatkan oleh tanaman sesaat setelah digunakan. Namun demikian, pemakaian pupuk anorganik secara terus-menerus akan dapat merusak kondisi tanah. Oleh karena itu dibutuhkan bahan organik agar kondisi tanah tetap terjaga baik sifat fisik, biologi dan kimianya. Pemberian bahan organik dapat dilakukan dengan cara memberikan pupuk organik pada tanah. Salah satu jenis pupuk organik yaitu pupuk kandang yang berasal dari limbah atau kotoran ternak seperti sapi, ayam, kambing, kuda dan lain sebagainya (Putra et al., 2017).

Tidak banyak desa yang memiliki hewan ternak berupa kuda. Namun di Kabupaten Burneh terdapat sebuah desa yang mempunyai peternakan kuda yaitu Desa Binoh. Salah satu hal yang bisa dimanfaatkan dari kuda adalah kotorannya. Banyaknya kotoran kuda di desa ini belum dimafaatkan dengan baik. Kotoran kuda bisa dimanfaatkan sebagai dasar pembuatan pupuk kandang/organik (Raifannur et al., 2017; Putra et al., 2017). Oleh karena itu maka merupakan hal yang menarik dan bermanfaat untuk melakukan pembuatan pupuk organik dengan memanfaatkan kotoran kuda serta mengaplikasikan hasilnya dalam bentuk vertikultur.

Desa Binoh merupakan desa yang terletak di Kecamatan Burneh, Kabupaten Bangkalan. Desa ini memiliki 6 dusun yang terdiri dari Dusun Tona'an, Dusun Musangar, Dusun Binoh Tengah, Dusun Duko, Dusun Gudur, dan Dusun Taman Dikeh. Desa ini memiliki potensi alam yang asri dan beragam seperti adanya bukit di sis selatan dari balai Desa Binoh. Selain itu, jenis pertanian yang banyak ditemui di desa ini adalah kacang tanah, jagung, dan tanaman palawija lainnya. Desa Binoh juga memiliki kampung KB dan kampung kependudukan yang ditujukan untuk akses informasi guna pembangunan indeks manusia di desa tersebut. Selain kampung KB dan kelompok pertanian yang dimiliki oleh Desa Binoh, potensi lain yang diunggulkan 
adalah peternakan kuda pacu yang menjadi salah satu keunikan tersendiri saat datang ke desa ini.
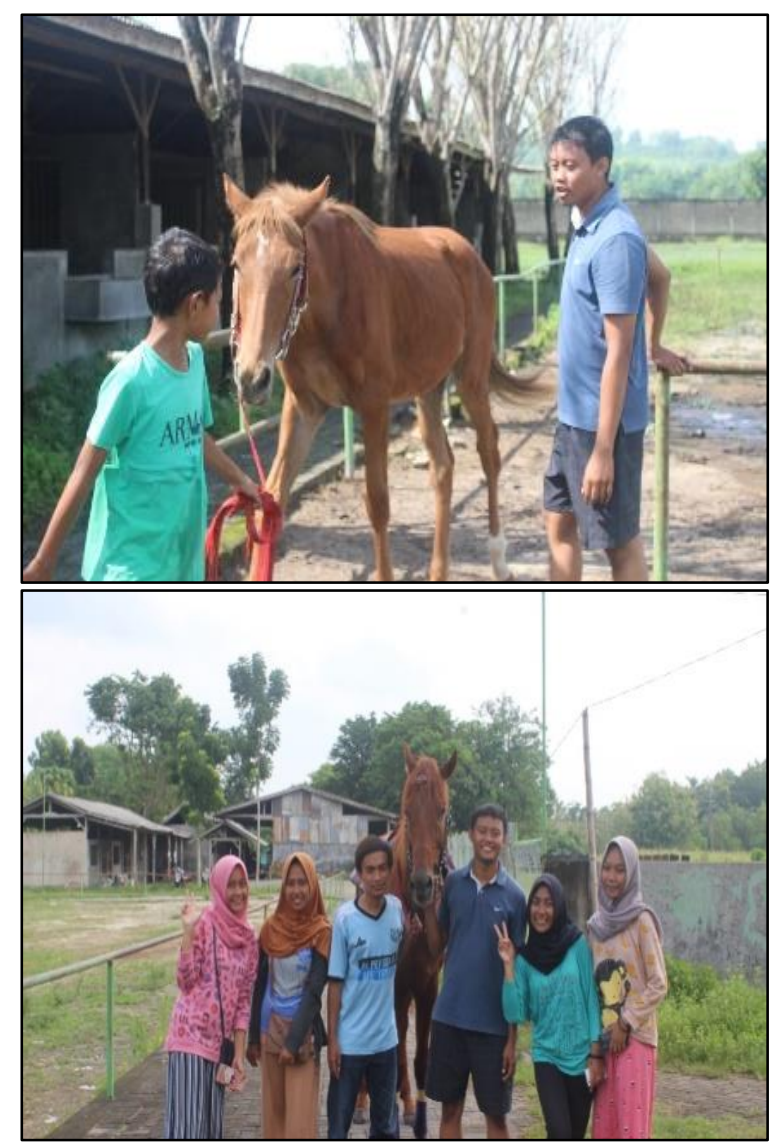

Gambar 1. Peternakan Sapi Desa Binoh

\section{METODE}

Kegiatan ini dilakukan pada tanggal 11 Januari 2019 bertempat di Desa Binoh yang merupakan salah satu desa yang terdapat di Kecamatan Burneh, Kabupaten Bangkalan, Madura, Jawa Timur.

\section{Alat dan bahan}

Bahan yang digunakan dalam kegiatan ini yaitu bakteri EM4, gula, air, kotoran kuda, arang skam dan dedak, sedangkan alat yang digunakan yaitu gergaji, paku, ember karung, bambu, skok dan cangkul.

\section{Pembuatan Pupuk dari Kotoran Kuda}

Adapun tata cara pembuatan pupuk dari kotoran kuda, yaitu :

a) Menyiapkan larutan yang merupakan hasil campuran antara bakteri EM4, gula dan air. Semua bahan tersebut harus dibuat tercampur sempurna.

b) Membuat campuran bahan yang tercampur merata antara: kotoran kuda, sekam dan dedak.

c) Menyiram campuran bahan dengan larutan EM4. d) Pencampuran dilakukan secara perlahanlahan dan merata hingga kandungan air \pm 30 $40 \%$. Kandungan air yang diinginkan kemudian diuji dengan menggenggam bahan. Pencampuran yang sempurna ditandai dengan tidak menetesnya air bila bahan digenggam dan akan mekar bila genggaman dilepaskan.

e) Bahan yang telah dicampur kemudian diletakkan di atas tempat yang kering atau dapat juga dimasukkan kedalam ember atau karung, kemudian dibiarkan selama 4 7 hari.

f) Setelah bahan menjadi bokashi, karung goni dapat dibuka. Bokashi ini dicirikan dengan warna hitam, gembur, tidak panas, dan tidak berbau. Dalam kondisi seperti itu, bokashi telah dapat digunakan sebagai pupuk.

\section{HASIL DAN PEMBAHASAN Pupuk Organik}

Pupuk organik adalah pupuk yang dibuat dari bahan-bahan organik atau alami seperti pelapukan sisa-sisa tanaman, hewan dan manusia. Pupuk organik dapat berbentuk padat atau cair yang digunakan untuk memperbaiki sifat fisik, kimia dan biologi tanah. Pupuk organik mengandung banyak bahan organik daripada kadar haranya. Bahan-bahan yang termasuk pupuk organik antara lain pupuk kandang, kompos, kascing, gambut, rumput laut dan guano. Berdasarkan bentuknya pupuk organik dapat dikelompokkan menjadi pupuk organik padat dan pupuk organik cair. Pupuk organik memiliki kandungan hara yang lengkap. Bahkan di dalam pupuk organik juga terdapat senyawa-senyawa organik lain yang bermanfaat bagi tanaman seperti asam humik, asam sulfat dan senyawa organik lainnya.

Pupuk kandang merupakan pupuk yang berasal dari kotoran hewan ternak, baik padat maupun cairan biasanya tercampur dengan sisasisa makanan. Pupuk kandang mempunyai peranan yang sangat penting, antara lain:

a. Merupakan humus (bunga tanah). Humus ini menjaga atau mempertahan stuktur tanah, sehingga tanah mudah diolah (ringan) dan terisi banyak oksigen.

b. Sebagai sumber hara nitrogen, fosfor dan kalium yang sangat penting bagi pertumbuhan dan perkembangan tanaman.

c. Meningkatkan kemampuan menahan air (water capacity). 
d. Banyak mengandung mikroorganisme yang dapat menghancurkan sampah-sampah organisme di dalam tanah sehingga berubah menjadi humus.

\section{Pupuk Kotoran Kuda}

Pupuk yang berasal dari kotoran kuda termasuk pupuk yang mudah mengalami penguraian. Hal ini karena susunan kimianya mengandung senyawa-senyawa yang memungkinkan bakteri-bakteri berkembang dengan aktif. Adanya penguraian yang cepat maka pemakaian atau pembenaman pupuk kuda yang telah matang sebaiknya dilakukan satu minggu sebelum masa tanam. Hal ini dilakukan untuk mencegah hilangnya unsur hara yang terkandung (Sutejo, 1999).

Pupuk kandang sangat bermanfaat bagi pertumbuhan tanaman karena dengan pemberian pupuk kandang dapat mengisi dfisit hara atau dapat dipergunakan secara langsung sebagai nutrisi tanaman. Tisdal dan nelson in Sarief (1986) menjelaskan bahwa kandungan unsur hara pada hewan berbeda-beda. Tabel 1 menunjukkan perbedaan kandungan unsur hara pada jenis ternak yang berbeda.

\section{Pembuatan Pupuk Kandang}

Kegiatan pembuatan pupuk kandang dilakukan bersama kelompok tani dari Desa Binoh dan mahasiswa KKN Universitas Trunojoyo Madura Kelompok tani begitu serius memperhatikan jalannya sosialisasi dengan memperhatikan dan mempelajari buku panduan yang telah diberikan sebelumnya. Dalam acara tersebut, diberikan juga kesempatan kepada para peserta kegiatan untuk mengajukan pertanyaanpertanyaan. Dalam sesi tanya jawab tersebut, masyarakat begitu antusias untuk menanyakan segala hal terkait dengan pupuk kandang dengan menggunakan kotoran kuda. Dari kegiatan tersebut dapat diketahui bahwa masyarakat belum pernah menggunakan kotoran kuda sebagai bahan dasar dalam pembuatan pupuk. Masyarakat hanya menggunakan kotoran sapi yang diletakkan ke berbagai tanaman yang dimilikinya tanpa mengolah dengan campuran bahan-bahan yang lain. Oleh karena itu, dengan adanya sosiliasasi dan praktik langsung kepada masyarakat diharapkan masyarakat tidak langsung meletakkan kotoran sapi pada tanaman yang dimilikinya, namun diolahnya terlebih dahulu dengan berbagai bahan-bahan yang telah dijelaskan. Selain itu, masyarakat juga dapat menggunakan kotoran hewan yang lainnya seperti kuda, ayam, dan lain-lain.
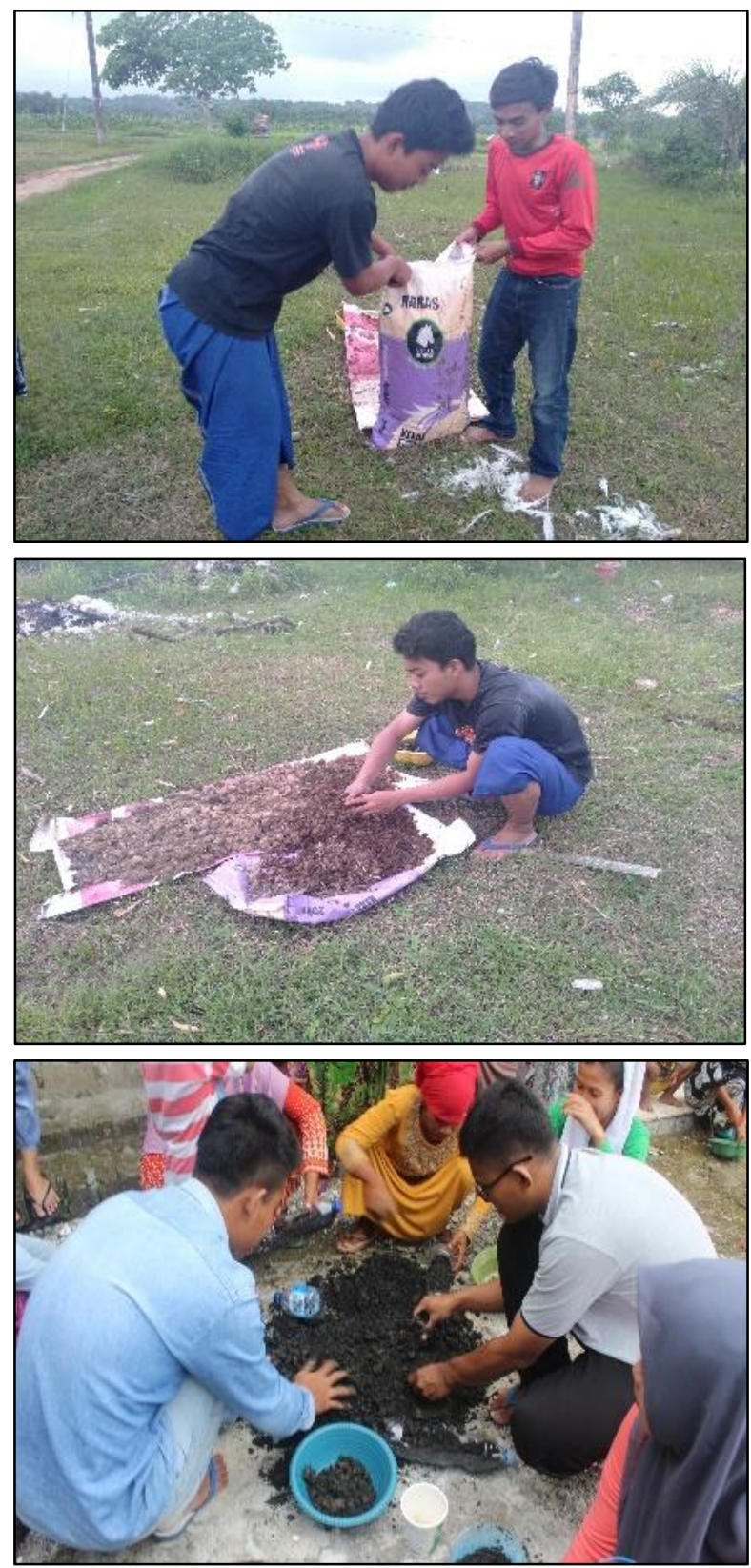

Gambar 2. Proses Pembuatan Pupuk Kandang dari Kotoran Kuda oleh Mahasiswa KKN

\section{Pembuatan vertikultur}

Setelah pembuatan pupuk tersebut, hasilnya kemudian dengan dimanfaatkan untuk kegiatan vertikultur. Vertikultur merupakan teknik penanaman vertikal atau bertingkat untuk memperindah pekarangan rumah dan memanfaatkan lahan yang sempit (Gambar 4). Sasaran utama kegiatan pembuatan vertikultur ini berfokus kepada para ibu-ibu karena untuk mengisi waktu kosong di rumah ketika tidak ada aktivitas lainnya. Pembuatan vertikultur bisa menggunakan bambu, paralon, ataupun 
Tabel 1. Susunan Unsur Hara dari Beberapa Pupuk Kandang

\begin{tabular}{|l|l|l|c|c|c|c|}
\hline Jenis ternak & Kotoran & $\%$ & $\mathrm{H}_{2} \mathrm{O}(\%)$ & $\mathrm{N}(\%)$ & $\mathrm{P}_{2} \mathrm{O}_{5}(\%)$ & $\mathrm{K} 2 \mathrm{O}(\%)$ \\
\hline Kuda & Padat & 80 & 75 & 0,55 & 0,30 & 0,40 \\
& Cair & 20 & 90 & 1,35 & - & 1,25 \\
& Total & - & 78 & 0,70 & 0,25 & 0,55 \\
\hline Sapi & Padat & 80 & 85 & 0,40 & 0,20 & 0,10 \\
& Cair & 20 & 92 & 1,00 & 0,20 & 1,35 \\
& Total & - & 86 & 0,60 & 0,15 & 0,45 \\
\hline Kambing & Padat & 80 & 60 & 0,75 & 0,50 & 0,45 \\
& Cair & 20 & 85 & 1,35 & 0,05 & 2,10 \\
& Total & - & 69 & 0,95 & 0,35 & 1,00 \\
\hline Babi & Padat & 80 & 80 & 0,55 & 0,35 & 0,45 \\
& Cair & 20 & 97 & 0,40 & 0,10 & 0,45 \\
& Total & - & 87 & 0,50 & 0,35 & 0,40 \\
\hline Ayam & Total & - & 55 & 1,00 & 0,80 & 0,40 \\
\hline
\end{tabular}

\section{Sumber : Sarief. 1986}

gelas plastik bekas sebagai media yang akan diisi tanaman seperti sayuran ataupun bunga.
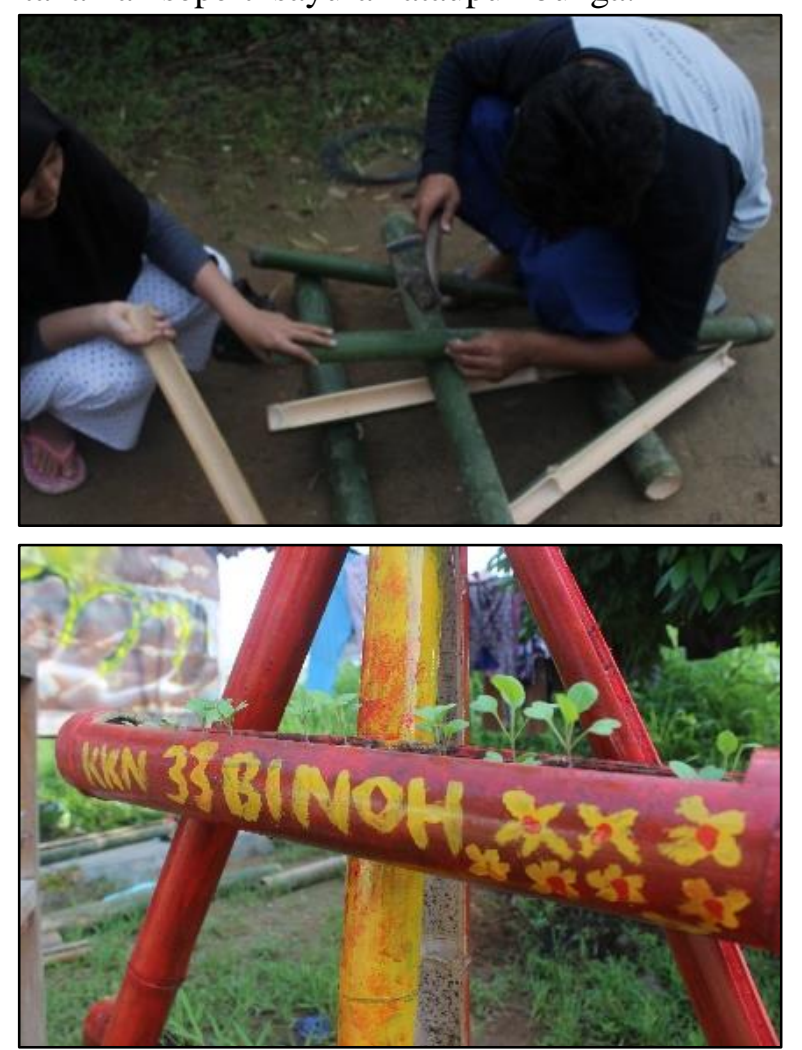

Gambar 3. Pembuatan Vertikultur oleh Mahasiswa KKN

Dalam kegiatan ini, media yang digunakan dalam pelatihan adalah plastik. Namun demikian, dari pelatihan vertikultur yang pertama ini didapatkan informasi dari masyarakat bahwa media dari gelas plastik bekas merupakan bahan yang mudah untuk digunakan. Oleh karena itu 2 hari setelah pelatihan yang pertama diadakan pelatihan vertikultur yang kedua dengan menggunakan bahan gelas plastik bekas. Gelas plastik bekas tersebut diperoleh dari warga setempat. Masyarakat berbondong-bondong datang ke lokasi pelatihan dengan semangat untuk belajar membuat vertikultur dengan menggunakan gelas plastik bekas. Campuran pupuk dari kotoran kuda tersebut hasilnya dapat dikatakan berhasil karena sayuran yang ditanam di vertikultur dapat tumbuh dengan baik.

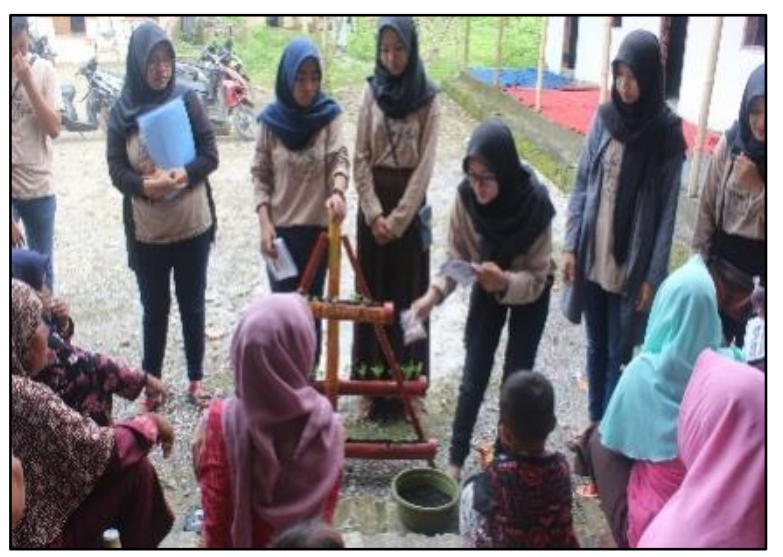

Gambar 4. Penjelasan Manfaat Vertikultur kepada Masyarakat

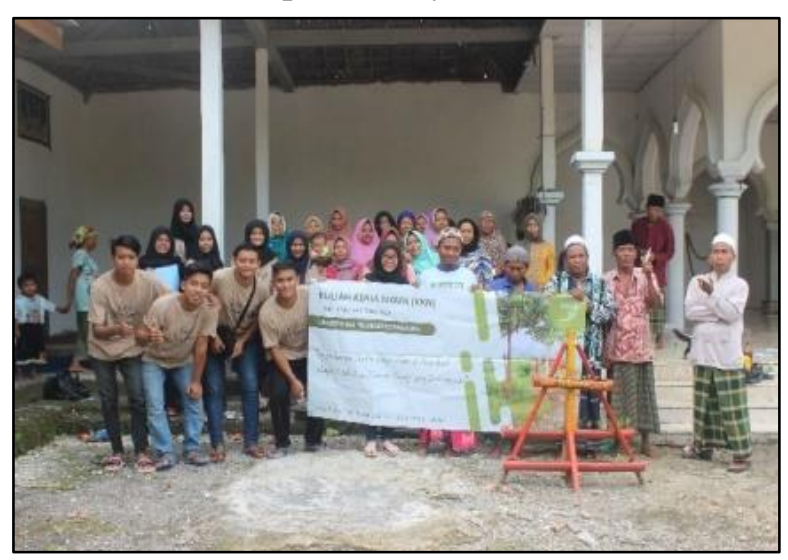

Gambar 5. Mahasiswa KKN Desa Binoh 


\section{KESIMPULAN}

Kotoran kuda dapat digunakan sebagai salah satu bahan dasar dalam pembuatan pupuk organik. Kegiatan pembuatan pupuk organik dengan memanfaatkan kotoran kuda yang banyak terdapat di Desa Binoh sangat dirasakan manfaatnya oleh masyarakat setempat. Kegiatan ini dinilai bisa mengatasi permasalahan yang ada di desa tersebut dan diharapkan dapat meningkatkan kesejahteraan masyarakat.

\section{DAFTAR PUSTAKA}

Kofranek, A. M. 1980. Cut Chrysanthemum in R.A. Larson (Ed). Introduction to floriculture. Academy Press. Toronto. p.545

Putra, M. F. D., Maghfoer, M, D and Koesriharti.
2017. Pengaruh Jenis Pupuk Kandang Dan Dosis Pupupk NPK pada Hasil Tanaman Krisan (Chrysanthemum Sp.). Pustaka Buana. Bandung

Raifannur, Rahimi, S.A.E., and Hasri, I. 2017. Kombinasi Pemberian Pupuk Kotoran Kuda dengan Pupuk Limbah Kulit Kopi Terhadap Petumbuhan dan Biomassa Azolla Microphylla. Jurnal Imiah Mahasiswa Kelautan dan Perikanan Unsyiah, 2(1): 141 - 149

Sutejo. 1999. Pupuk dan Cara Pemupukan. Rineka Cipta. Jakarta.

Sarief, E. 1986. Kesuburan dan Pemupukan Tanah Pertanian. Pustaka Buana. Bandung. 